\title{
Phytochemical Investigation and Pharmacognostic Standardization of Polycarpaea corymbosa Lam
}

\author{
Karuna Modi, Mamta Shah*
}

\section{Karuna Modi,}

\section{Mamta Shah*}

Department of Pharmacognosy,

L. M. College of Pharmacy, Navrangpura, Ahmedabad, Gujarat, INDIA.

\section{Correspondence}

Dr. Mamta B. Shah

Associate Professor and Head, Department of Pharmacognosy, L. M. College of Pharmacy, Navrangpura, Ahmedabad: 380 009, Gujarat, INDIA.

Phone no: 09825766869

E-mail: mbshah2007@rediffmail.com

\section{History}

- Submission Date: 26-04-2017.

- Review completed: 08-06-2017;

- Accepted Date: 31-08-2017

DOI : 10.5530/pj.2017.6.140

Article Available online http://www.phcogj.com/v9/i6

\section{Copyright}

(c) 2017 Phcog.Net. This is an openaccess article distributed under the terms of the Creative Commons Attribution 4.0 International license.

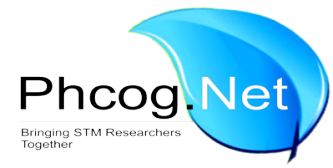

\begin{abstract}
Background: Polycarpaea corymbosa is one of the plants cited as 'Parpata' in Ayurvedic literature and indicated for boils, inflammatory swellings, and ulcers. Aim: The present study is an attempt to generate and encompass the data of physical parameters for ascertaining the identification and develop a validated HPTLC method for quantification of lupeol in P. corymbosa. Materials and Methods: The whole plant was studied for establishing pharmacognostic standards including macro and microscopical characters, physico-chemical analysis and quantification lupeol by HPTLC method. Results: It is a small, much branched, erect or spreading herb with linear leaf and silvery-white cymes. Microscopically root can be connoted by continuous or discontinuous concentric rings of xylem and phloem; stem by papillose epidermis with multicellular branched collapsed and glandular trichomes, sclerenchymatous pericycle and hollow pith; and leaf by numerous collateral meristele enclosed within parenchymatous bundle sheath. Further studies evinced that brunt of heavy metal and microbial load in plant material was within permissible limits. Flavonoids, phenolics and saponins were found be major components. HPTLC method was developed for quantification of lupeol using precoated silica gel plates as a stationary phase, and toluene: methanol (9.4: 0.6) as a mobile phase and scanning the plate at $545 \mathrm{~nm}$. Conclusion: The information demonstrated on pharmacognostic parameters and validated HPTLC method for estimation of lupeol for Polycarpaea corymbosa, would aid as coherent measures for its assessment.
\end{abstract}

Key words: HPTLC, Lupeol, Parpata, Pharmacognostic study, Polycarpaea corymbosa.

\section{INTRODUCTION}

Polycarpaea corymbosa Lam. (Caryophyllaceae) is commonly known as 'Jinapanano oghrad' or 'Parpata' in Gujarat. ${ }^{1,2}$ It is an erect, annual, slender dichotomously branched herb distributed in fields, waste places and sandy river banks almost throughout India during winter. ${ }^{2,3}$ The plant is highly valued in traditional medicine in the treatment of urinary calculi, boils, inflammatory swellings, and ulcers. ${ }^{4-6}$ In Pudukotah, the herb is administered both externally and internally as a remedy for the bites from venomous reptiles and animals, and given with molasses in the form of a pill in jaundice. In Malaya, the drug is used as demulcent and astringent. ${ }^{6}$ In literature the plant is recorded to possess hepatoprotective, cytotoxic, antioxidant and antiradical activities. ${ }^{7-9}$ Also, it has been documented to contain camelliagenin A, A1-barrigenol, stigmastanol, apoanagallosaponin IV, $n$-hexadecanoic acid and 5-hydroxymethyl furfural along with some phenols and flavanoids. ${ }^{9-11}$ Lupeol, a triterpenoid, is reported to be having multiple biological actions noticeably anti-inflammatory, hepatoprotective, antiprotozoal, antimicrobial, chemoproptective etc. ${ }^{12-14}$ In the present study, we here propose data for development of a comprehensive monograph, a requisite for quality assessment. Further, the HPTLC method for estimation of lupeol has been validated for linearity, interday and intraday precision, repeatability, accuracy, specificity, limit of detection and limit of quantification.

\section{MATERIALS AND METHODS}

\section{Plant material}

Fresh, fully-grown, flowering plants of $P$. corymbosa were collected from Tirunelveli, Tamilnadu. The plants collected were authenticated by taxonomist of Gujarat University, Ahmedabad, Gujarat. Voucher specimen (LM 633) was deposited at the Department of the authors. The plant material was cleaned, dried, powdered to 60 \# and used for the present study.

\section{Chemicals and reagents}

Standard lupeol was procured from Sigma Aldrich, India. All the solvents used were of chromatography grade and other chemicals used were of analytical (AR) grade. 


\section{Pharmacognostical studies}

The whole plant was studied for morphological characters. Microscopical study was performed for different plant parts (free hand transverse sections) and powdered material of entire plant.

Ash values and extractive values were determined. ${ }^{15}$

\section{Heavy metal analysis}

Heavy metals analysis for lead $(\mathrm{Pb})$, mercury $(\mathrm{Hg})$ and arsenic (As) was carried out for powdered herb. Their concentrations were determined by Inductively Coupled Plasma Optical Emission Spectrometry (Perkin Elmer-Optima $3300 \mathrm{RL}$ ).

\section{Determination of microbiological parameters}

The microbiological parameters like total plate count, yeast and mould count, E. coli, Staphylococcus aureus and Salmonella spp. were investigated in powdered herb. Results obtained were compared with limits for each microorganism.

\section{Phytochemical studies}

Phytochemical screening was performed ${ }^{16}$, and flavonoids, phenolics ${ }^{17}$ and saponins ${ }^{18}$ were estimated.

\section{Extraction}

$5 \mathrm{~g}$ drug powder was exhaustively extracted with $100 \mathrm{ml}$ methanol, filtered and dried. The methanolic extract was hydrolysed by refluxing with $70 \mathrm{ml} \mathrm{1:1} \mathrm{mixture} \mathrm{of} \mathrm{toluene:2N} \mathrm{HCL} \mathrm{for} 2 \mathrm{~h}$. After neutralizing with sodium carbonate, it was extracted with toluene (3X $25 \mathrm{ml})$ and vacuum dried to yield $18 \% \mathrm{w} / \mathrm{w}$ of extract (Ext A). ${ }^{19}$

\section{Estimation of lupeol by HPTLC method Chromatographic conditions}

HPTLC was performed on $10 \mathrm{~cm} \times 10 \mathrm{~cm}$ precoated silica gel $60 \mathrm{~F}_{254}$ plates (E. Merck, Germany). Before chromatography the plates were pre-washed by methanol and activated at $60^{\circ} \mathrm{C}$ for $5 \mathrm{~min}$. Samples were applied to the plates as bands $6 \mathrm{~mm}$ wide and $12.2 \mathrm{~mm}$ apart using Camag Linomat V applicator (Muttenz, Switzerland) fitted with a 100 microlitre syringe (Camag, Switzerland). Linear ascending development was performed in Camag twin-trough glass chamber $(10 \times 10 \mathrm{~cm})$ with mobile phase vapour [toluene: methanol, 9.4: 0.6] at room temperature $\left(25 \pm 2^{\circ} \mathrm{C}\right)$. Plate was dried and derivatized using anisaldehyde sulfuric acid reagent in CAMAG derivatization chamber followed by heating at $110^{\circ} \mathrm{C}$ using Camag TLC plate heater. It was scanned in Camag TLC scanner using WinCATS software (version 1.4.3.6336) in absorption mode at $545 \mathrm{~nm}$ with slit dimensions $6.00 \times 0.45 \mathrm{~mm}$. The scanning speed was $20 \mathrm{~mm} / \mathrm{sec}$ and source of radiation tungsten lamp.

The method was validated in terms of linearity, interday precision, intraday precision, repeatability, accuracy, specificity, limit of detection and limit of quantification. International Conference on Harmonization (ICH) guideline was employed for validation of analytical method. ${ }^{20}$

\section{Calibration curve}

A stock solution $\left(100 \mu \mathrm{g} \mathrm{ml}^{-1}\right)$ of lupeol was prepared by dissolving accurately weighed $1 \mathrm{mg}$ in $10 \mathrm{ml}$ methanol in a volumetric flask. Standard solutions for calibration were prepared by dilution of the stock solution with methanol; the concentrations were such that amounts of lupeol between 100-500 ng. The correlation coefficient, slope intercepts and regression equation were also calculated to provide mathematical estimate degree of linearity. A calibration curve was derived by plotting peak area ( $\mathrm{Y}$ axis) versus concentration ( $\mathrm{X}$ axis).

\section{Quantification of lupeol in extract}

$10 \mathrm{mg}$ of Ext A was dissolved in $2 \mathrm{ml}$ methanol in a volumetric flask. $30 \mu \mathrm{l}$ of this solution was used for estimation lupeol. The peak area values of standards and sample were used to calculate the amount of lupeol in the plant.

\section{RESULTS AND DISCUSSION}

Polycarpaea corymbosa is an annual, erect, $10-40 \mathrm{~cm}$ tall, branched, and slender herb. Morphologically it can be characterized by its simple, whorled, sessile, linear leaves, with entire margin and mucronate apex; numerous slender, erect or spreading, pubescent stems; slender and woody roots with thin wiry rootlets and silvery-white, crowded, terminal cymes (Figure 1).

\section{Microscopical characters}

Microscopical examination (TS) revealed that a suberized cork (ck) made up of 5-7 layers of tangentially elongated cells; narrow thin walled parenchymatous cortex (ct); phloem (ph) traversed with clefts of medullary rays $(\mathrm{mr})$; lignified radially arranged xylem (xy) consisting of vessels and thick walled fibres (Figure 2) are structural features of root. Further, a layer of tangentially elongated, thick walled papillose epidermis (e) bearing multi-cellular branched and collapsed covering and glandular trichomes with unicellular head and stalk; cortex (ct) with compressed chlorenchyma; scelerenchymatous pericycle (per) associated with stone cells; stele constituted of narrow band of phloem (ph) and central xylem (xy) wide, parenchymatous, hollow pith (pi) (Figure 3) are distinctive features of stem. Moreover, the presence simple covering multicellular branched and collapsed trichomes in papillose epidermis (e); a line of collateral meristele (mer) enclosed within parenchymatous bundle sheath (bs), central one being associated with fibres on lower side; narrow spongy parenchymatous tissue embedded with rosettes of calcium oxalate and tanniniferous substances (Figure 4) are characteristic of leaf. Presence of branched and collapsed trichomes ( $\mathrm{a}$ and $\mathrm{b}$ ), spherical pollen grains with smooth exine (c) and rosettes of calcium oxalate in epidermis of leaf (d) (Figure 5) are selected representative lineaments of powdered plant material.

\section{Heavy metal analysis}

All the heavy metals are found within permissible limits as per WHO guidelines. ${ }^{21}$ The results have been summarized in Table 1.

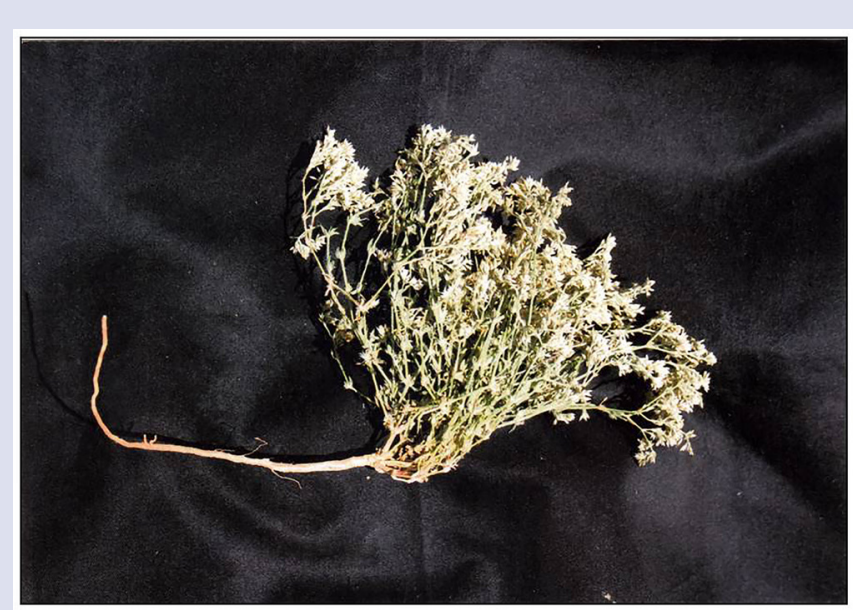

Figure 1: Herb of Polycarpaea corymbosa Lam. 


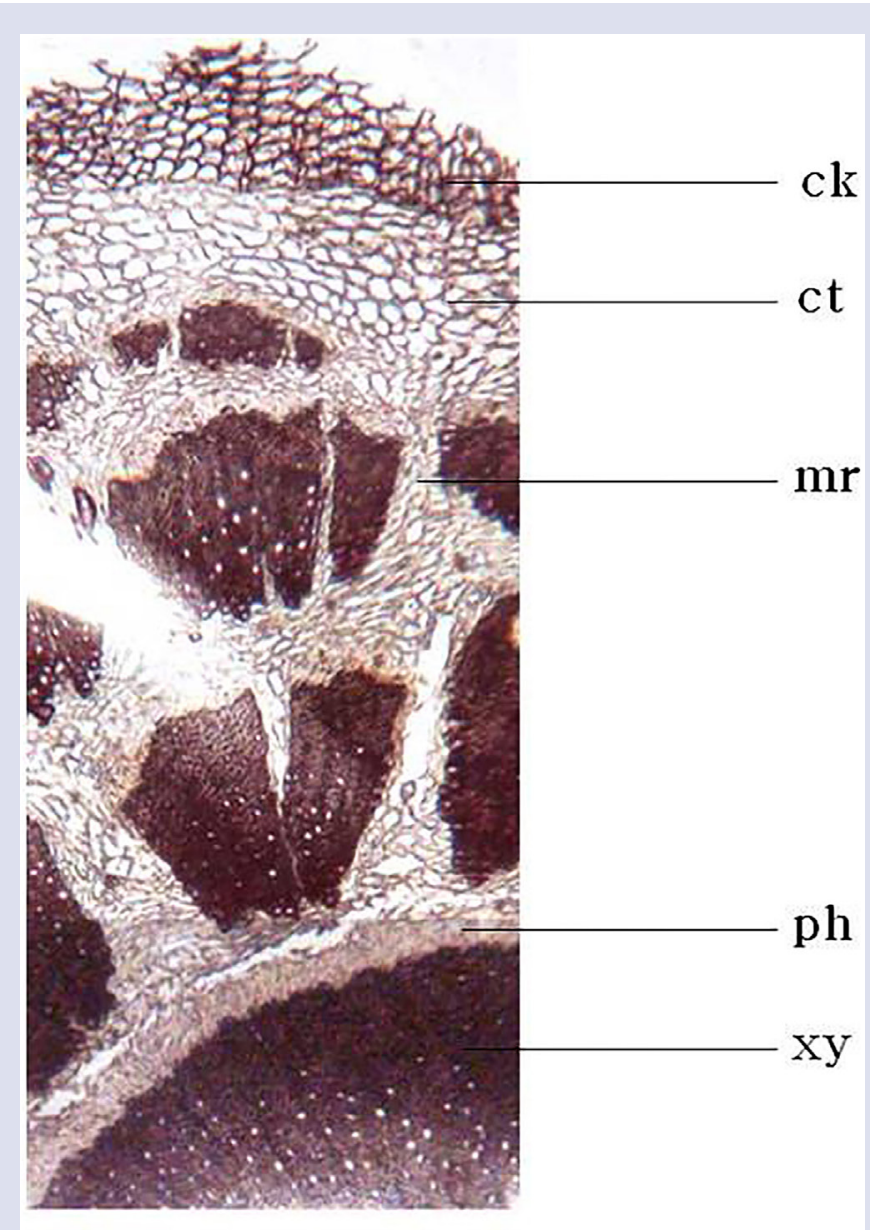

Figure 2: TS of $\mathrm{P}$. corymbosa root.

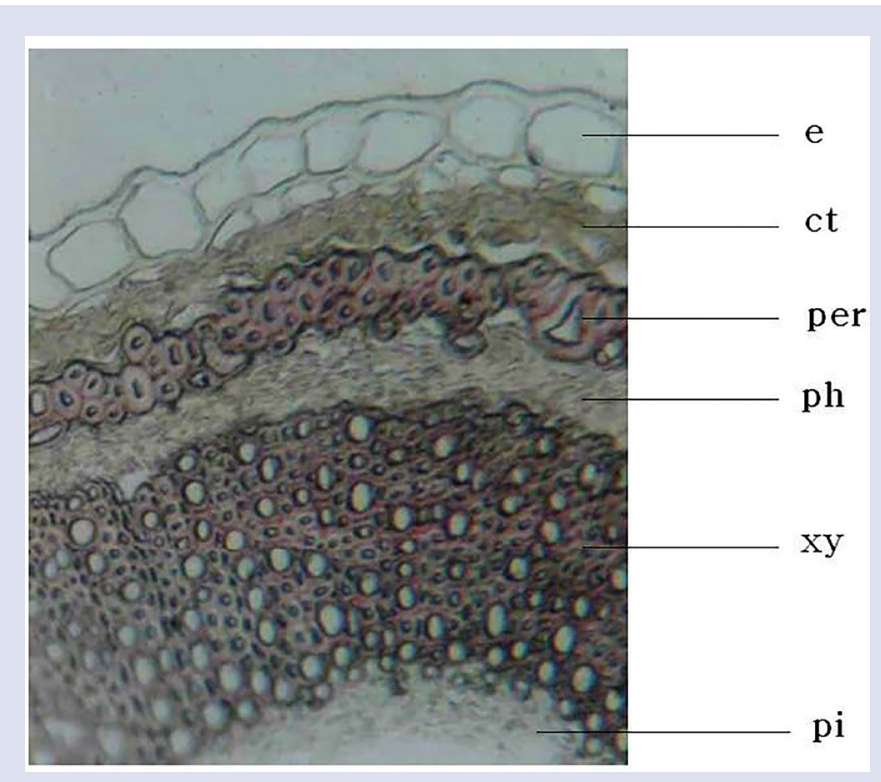

Figure 3: TS of $P$. corymbosa stem.

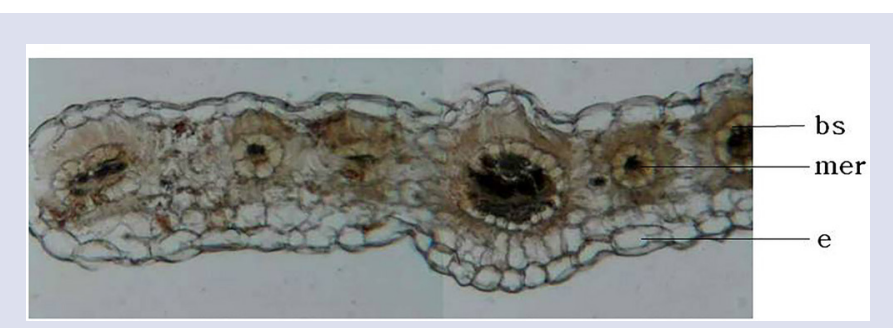

Figure 4: TS of $P$. corymbosa leaf.
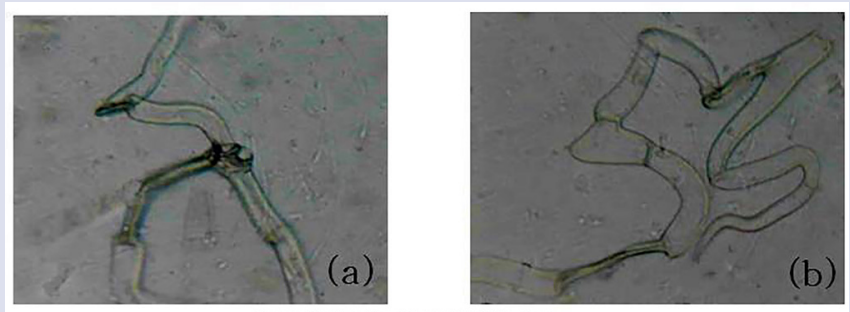

Branched and collapsed trichornes

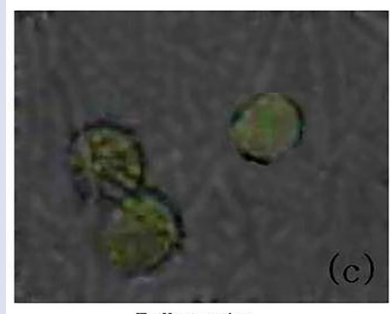

Pollen grains

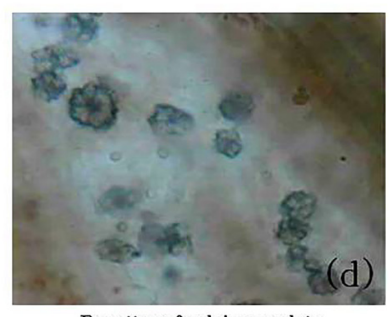

Rosettes of calciurn oxalate
Figure 5: Powder characters of $P$. corymbosa whole plant.

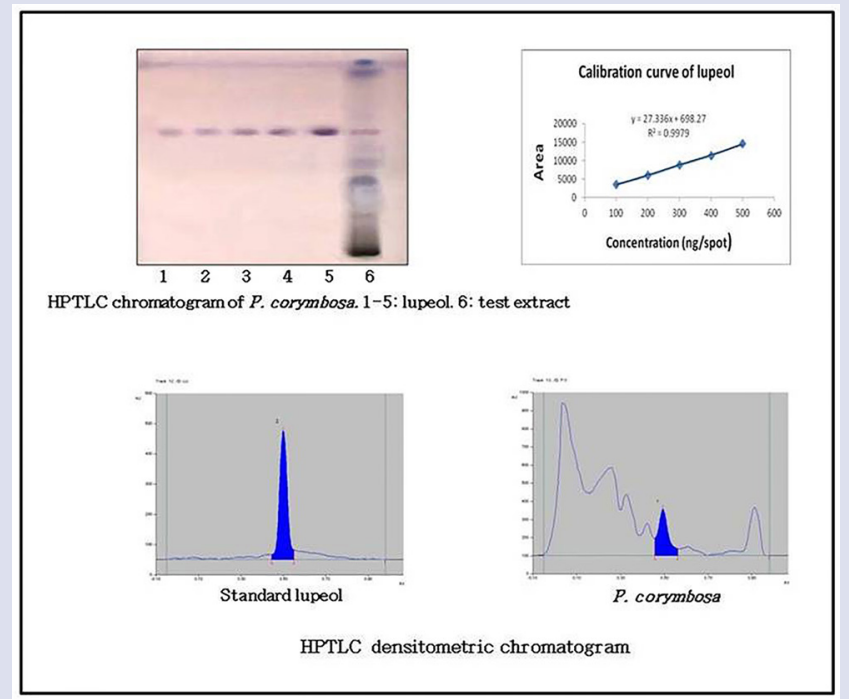

Figure 6: HPTLC study. 
Table 1: Heavy metal analysis.

\begin{tabular}{cc}
\hline Elements & Results (ppm) \\
\hline Lead $(\mathrm{Pb})$ & $\mathrm{BDL}^{1}$ \\
Mercury $(\mathrm{Hg})$ & $\mathrm{BDL}$ \\
Arsenic $(\mathrm{As})$ & $\mathrm{BDL}$ \\
\hline
\end{tabular}

1. BDL: Below detection limit, ppm: parts per million Instrument Detection Limits: Pb: 0.0420 ppm; Hg: 0.0610 ppm and As: $<0.0530$ ppm.

Table 2: Microbiological parameters.

\begin{tabular}{cc}
\hline Parameters & Results \\
\hline Total Plate Count & $34200 \mathrm{cfu} / \mathrm{g}^{2}$ \\
Yeast and Mould Count & $<10 \mathrm{cfu} / \mathrm{g}$ \\
Escherichia coli & Absent \\
Salmonella spp. & Absent \\
Staphylococcus aureus & Absent \\
\hline
\end{tabular}

2. Cfu/g: Colony forming units/gm

Table 3: Physico-chemical parameters.

\begin{tabular}{lc}
\hline \multicolumn{1}{c}{ Quality Parameters } & $\%$ w/w \pm S.D. ${ }^{3}$ \\
\hline Ash value & \\
a. Total ash value & $8.38 \pm 1.18$ \\
b. Acid insoluble ash & $1.75 \pm 0.29$ \\
c. Water soluble ash & $4.37 \pm 0.54$ \\
Extractive value & \\
a. Water soluble extractive & $20.0 \pm 0.35$ \\
b. Alcohol Soluble extractive & $1.5 \pm 0.22$ \\
\hline
\end{tabular}

3. $\mathrm{SD}=$ standard deviation, Number of readings $=3$

Table 4: Content of phytoconstituents.

\begin{tabular}{cc}
\hline Phytoconstituents & $\% \mathrm{w} / \mathrm{w} \pm$ S.D. \\
\hline Flavonoids & $3.44 \pm 0.45$ \\
Phenolics & $5.69 \pm 0.16$ \\
Saponins & \\
Froth number & $250.34 \pm 0.13$ \\
\hline
\end{tabular}

Table 5: Summary of validation parameters of lupeol.

\begin{tabular}{lc}
\multicolumn{1}{c}{ Parameters } & Results \\
\hline Linearity (R2) & 0.9979 \\
Precision (C.V.) & \\
- Repeatability of Measurement & 0.308 \\
- Repeatability of Application & 1.016 \\
- Interday & $2.03-3.18 \%$ \\
- Intraday & $1.58-1.89 \%$ \\
Range & $100-500 \mathrm{ng} / \mathrm{spot}$ \\
Limit of Detection & $20.66 \mathrm{ng} / \mathrm{spot}$ \\
Limit of Quantification & $62.6 \mathrm{ng} / \mathrm{spot}$ \\
Accuracy & $98.15-99.66 \%$ \\
Specificity & Specific \\
\hline
\end{tabular}

\section{Microbiological parameters}

The plant material is free of encumbrance of Salmonella spp. and microbial load is within the limits specified by WHO. ${ }^{22}$ The results have been mentioned in Table 2.

\section{Physicochemical evaluations}

Data of Physico-chemical parameters including ash and extractive values are given in Table 3. Low acid insoluble ash value yielded confirmed presence of more amount of inorganic matter in the form of rosettes. The plant showed higher water-soluble components than alcohol soluble components. Saponins, flavonoids and phenolics are among the major compounds present in the plant (Table 4).

\section{Estimation of lupeol by HPTLC analysis}

In Co-TLC studies of extract with the reference standard, lupeol was discernable at $\mathrm{R}_{\mathrm{f}} 0.51$ (Figure 6). Further, in HPTLC method developed, the same spots in both the tracks (extract and reference standard) showed superimposable UV spectra approving the identity. The content of lupeol was found to be $0.011-0.013 \% \mathrm{w} / \mathrm{w}$. The LOD and LOQ, for signal-to-noise ratios were $3: 1$ and 10:1, respectively. The particulars of validation parameters are given in Table 5.

\section{CONCLUSION}

This is the first report on the Pharmacognostic study expounded with HPTLC analysis for Polycarpaea corymbosa. The ensemble of data on standard parameters is useful for the endorsement of quality control and for documenting a monograph on this crude drug. The proposed HPTLC method for the estimation of lupeol is found to be precise, accurate and selective. It does not suffer any positive or negative interference due to other common components present in the extract. Thus, it can be applied to obtain the necessary authentication of $P$. corymbosa routinely, with good reliability and reproducibility. The present study proffers, an expedient tool to corroborate the drug through good constancy by addressing the realistic issue of qualitative analysis of the plant material in terms of botanical identification and quantification of lupeol by HPTLC.

\section{REFERENCES}

1. Vaidya B. The controversial drugs in Indian Medicine. 1st ed. Varanasi: Chaukhambha Orientalia. 1982.p.207-11

2. Anonymous. The Wealth of India (Raw materials). Vol. VIII. New Delhi: Council of Scientific and Industrial Research. 1969.p.189.

3. Gamble JS. Flora of the Presidency of Madras. Vol. I. Calcutta: Botanical Survey of India. 1957.p.46-7.

4. Nadkarni KM. Indian Materia Medica. Vol. I. $3^{\text {rd }}$ ed. Bombay: Popular Book Depot. 1954.p.997.

5. Husain A. Dictionary of Indian Medicinal Plants. Lucknow: Central Institute of Medicinal and Aromatic Plants. 1992.p.363.

6. Kirtikar KR, Basu BD. Indian Medicinal Plants. Vol. I. Delhi: M/S Periodical Experts. 1975.p.239-40.

7. Kiran RY, Manjunath C, Kumar RM, Brahmaiah Y, Kumar AU, Tamizhmani T. A review on traditional plants with hepatoprotective activity. Pharmacol Online. 2011;3:653-8

8. Abirami MS, Muthuswamy. Antioxidant potential, total phenolic and total flavonoids content of various extracts from whole plant of Polycarpaea corymbosa Lam. Asian J Pharm Clin Res. 2013;6(4):121-4.

9. Manase MJ, Mitaine OAC, Miyamoto T, Tanaka C, Delemasure S, Dutartre P, et al. Triterpenoid saponins from Polycarpaea corymbosa Lamk. var. eriantha Hochst. Phytochemistry. 2014;100:150-5.

10. Chiang HC. Studies on the constituents of Polycarpaea corymbosa Lam. Taiwan Yaoxue Zazhi. 1978;30(2):114-20.

11. Sindhu S, Manorama S. GC-MS determination of bioactive components of Polycarpaea corymbosa Lams. (Caryophyllaceae). Hygeia. 2013;5(1):5-9.

12. Modi K, Shah M. Pharmacognostic specifications and quantification of oleanolic acid and lupeol in Mollugo oppositifolia Linn. Phcog J. 2015;7(2):1-9.

13. Gallo MBC, Sarachine MJ. Biological activities of lupeol. Int J Biomed Pharm Sci. 2009;3(1):46-66. 
14. Modi K, Shah M. Determination of oleanolic acid, ursolic acid, lupeol and stigmasterol by HPTLC Method in Oldenlandia corymbosa Linn. J Planar Chromatogr. 2017;30(1):32-5.

15. Anonymous. Determination of ash value and extractive value. In: World Health organization, editor. Quality control methods for medicinal plant materials. 1st ed. Delhi: A.I.T.B.S. Publishers and distributors. 2002.p.28-30.

16. Shah MB, Marfatia SH, Shah UD, Sheth NR. Textbook of Pharmacognosy-II. 1st ed. Ahmedabad: Nirav and Roopal Prakashan. 2010.p.61.

17. Kalola J, Shah M. Free radical scavenging activity of Inula cappa. Ars Pharm. 2006;47(4):387-8.

18. Anonymous. Determination of foaming index. In: World Health organization, editor. Quality control methods for medicinal plant materials. 1st ed. Delhi: A.I.T.B.S. Publishers and distributors. 2002.p.46.
19. Weissenberg M. Isolation of solasodine and other steroidal alkaloids and sapogenins by direct hydrolysis-extraction of Solanum plants or glycosides therefrom. Phytochemistry. 2001;58(3):501-8.

20. ICH, Q1A (R2), Stability testing of new drug substances and products. International Conference on Harmonization, IFPMA, Geneva, Switzerland. 2003

21. Lohar DR. Protocol for testing of Ayurvedic, Siddha and Unani medicines Ghaziabad: Pharmacopoeial laboratory for Indian medicines, Ministry of Health and Family Welfare. 2007.p.35.

22. Araújo MGF, BauabTM. Microbial Quality of Medicinal Plant Materials. In: Akyar I, editor. Latest Research into Quality Control. Rijeka: InTech. 2012.p.67-81.

\section{GRAPHICAL ABSTRACT}

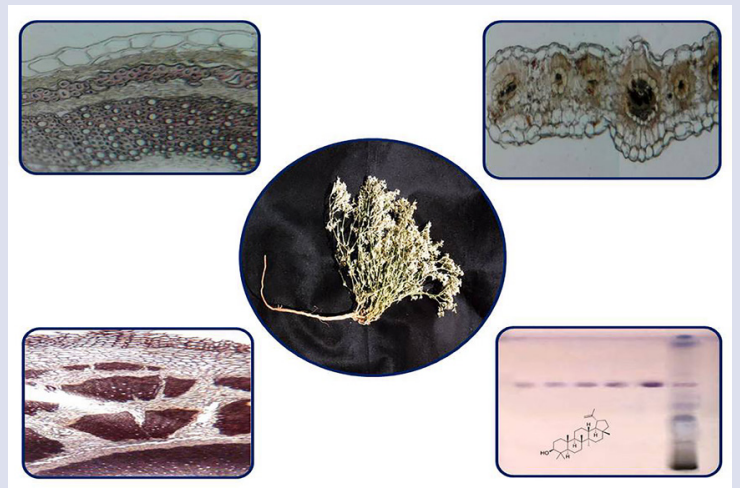

\section{SUMMARY}

Polycarpaea corymbosa is spreading herb with linear leaf and silvery-white cymes. It is used in traditional system of medicine for treatment of boils and inflammatory swellings. The study was aimed to generate the data of physical parameters for ascertaining the identification and develop a validated HPTLC method for quantification of lupeol in $P$. corymbosa using toluene: methanol (9.4: 0.6$)$ as a mobile phase. The information exhibited on pharmacognostic parameters and validated HPTLC method for estimation of lupeol for Polycarpaea corymbosa, would serve as articulate measures for its assessment.

\section{ABOUT AUTHORS}

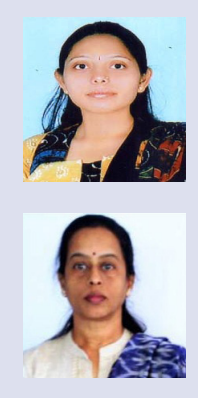

Ms. Karuna Modi, Assistant professor, Department of Pharmacognosy, L. M. College of Pharmacy, Navrangpura, Ahmedabad: 380 009, India.

Dr. Mamta Shah, Associate Professor and Head, Department of Pharmacognosy, L. M. College of Pharmacy, Navrangpura, Ahmedabad: 380 009, India.

Cite this article: Modi K, Shah M. Phytochemical Investigation and Pharmacognostic Standardization of Polycarpaea corymbosa Lam. Pharmacog J. 2017;9(6):895-9. 